\title{
MINING COMPANIES TAX AVOIDANCE BY THE COMPANY CHARACTERISTICS AND CSR: COMPANY SIZE AS THE MODERATING VARIABLE
}

\author{
Muhammad Wahyuddin Abdullah ${ }^{1 *}$, Jupaing2, Puspita Hardianti Anwar, \\ Hadriana Hanafie ${ }^{4}$ \\ 1,2,3Universitas Islam Negeri Alauddin Makassar, Indonesia \\ 4STIE Wira Bhakti Makassar, Indonesia
}

\begin{abstract}
This research aims to find the influence of capital intensity, sales growth, and CSR on tax avoidance and its strengthened impact on company size. The population in this study is all mining companies listed on the Indonesia Stock Exchange in 2014-2018. Determination of research samples based on purposive sampling method with a total of 85 data. Logistics regression analysis with MRA test with the strengthening company size. The results showed that capital intensity, sales growth, and CSR significantly positively affected tax avoidance. In addition, the results of this study also show that company size strengthens sales growth and CSR on tax avoidance with a significant favorable influence, and company size cannot strengthen capital intensity on tax avoidance.
\end{abstract}

Keywords: Capital intensity; Sales growth; Corporate social responsibility (CSR); Company size; Tax avoidance

Submitted: 11 March 2021; Revised: 05 \& 24 April 2021; Accepted: 28 April 2021

*Corresponding author: wahyuddin.abdullah@uin-alauddin.ac.id

DOI: $10.24252 /$ minds.v8i1.20250

ISSN-E: 2597-6990 


\section{INTRODUCTION}

Today's reality shows that there are still many companies that only attach importance to large profits so that they continue to do various ways to minimize their tax avoidance. Tax Avoidance is the arrangement of transactions by taxpayers to benefit or reduce taxes by exploiting existing legal loopholes (Brown 2012; in Fadjarenie and Anisah 2016). This case indicates no violation of the law committed by the company to obtain tax savings by utilizing loopholes in the applicable tax regulations (lawful) to improve its profitability and cash flow. The payment of taxes by the company to the government is not considered to provide direct benefits, so that the company sometimes finds it difficult to pay taxes (Dharma and Noviari, 2017).

Taxes are people's dues paid to the state under the law by not getting direct rewards and bills used for the public good (Adiatma et al., 2015). The definition of tax, according to (Hantoyo et al., 2016), is an obligation in the form of the transfer of income from a citizen (taxpayer) to a country based on laws imposed and used for the benefit of the state (public). Companies conduct tax avoidance due to several factors; one factor that can influence companies in achieving tax avoidance practices is the company's characteristics. The characteristics of the companies taken in this study are capital intensity ratio and sales growth. Capital Intensity Ratio is often associated with corporate capital embedded in fixed assets and supplies owned by the company (Putra and Merkusiwati, 2016).

Based on the analysis, tax morale improves taxpayers' awareness (Abdullah et al., 2020). This research is expected to motivate the company to be more transparent in presenting its annual report so that it can be relied on and consideration for investors to invest their shares in a company and is expected to consider the company manager to evaluate the performance and profit income of a company that can affect the sustainability and image of the company. This research is expected to provide essential insights for tax policymakers who seek to identify circumstances where the risk of corporate tax avoidance is higher to improve Law No. 36 of 2008 on Income Tax and Government Regulation No. 46 of 2013 on Income Tax on Income from Businesses Received or Obtained by Taxpayers who Have a Certain Gross Circulation.

Table 1. Realization of Tax Receipts in Indonesia

\begin{tabular}{cccc}
\hline Year & $\begin{array}{c}\text { Target } \\
\text { (Trillion } \\
\text { Rupiah) }\end{array}$ & $\begin{array}{c}\text { Realization } \\
\text { (Trillion Rupiah) }\end{array}$ & $\begin{array}{c}\text { Effectiveness of tax } \\
\text { adoption (percent) }\end{array}$ \\
\hline 2016 & $1.539,2$ & $1.283,6$ & 83,4 \\
2017 & $1.283,6$ & $1.147,5$ & 89,4 \\
2018 & $1.424,0$ & $1.315,9$ & 92,0 \\
\hline
\end{tabular}

Source: Adapted from www.kemenkeu.go.id (2019) 
There is a difference of interest between the taxpayer and the government when the taxpayer, in this case, seeks to pay the smallest amount of tax because it reduces the financial ability to carry out its operations. Meanwhile, the government as a tax collector aims to get the most revenue possible to finance the nation's interests and the state. This research is in line with the agency theory expressed by Jensen and Meckling (1976) that the contract in which one or more (principals) involve one person (agent) to perform services that are of principal interest in terms of separation of ownership and control of the company.

\section{THEORETICAL REVIEW}

\section{Agency Theory}

According to Jensen and Meckling (1976), agency theory is an agency relationship that arises when one or more principals hire another person (agent) to provide a service and then delegate decision-making authority. The agency's theory becomes a perspective that clearly describes the problems arising from the separation between ownership and control of the company, namely conflicts of interest in the company (Wardani and Khoiriyah, 2018). The difference of interest occurring in tax collection is the interest between the collectors and the company, where the principal (stakeholder) wants the most considerable amount of tax receipts from the public. In contrast, the company as an agent wants to pay taxes in the minimum amount to the state (Hardika, 2007). This difference of interest based on agency theory will lead to non-compliance by corporate management that will impact efforts to conduct tax avoidance.

\section{Legitimacy Theory}

Legitimacy theory is an idea of social contracts between companies and society. According to this theory, to be accepted by the public, the company must disclose the company's social activities to ensure the company's survival (Reverte, 2009). The theory of legitimacy also holds that companies should implement and elaborate CSR activities as much as possible for the company's activities to be accepted by the public. This disclosure is used to legitimize the company's activities in the public's eyes since CSR disclosure will indicate the company's level of compliance (Branco and Rodrigues, 2008). Dowling and Preffer (1975) stated that companies could gain legitimacy support from the community through two dimensions, namely the activities of the company's organization must comply with the existing value system in the community, and the reporting of corporate activities should reflect the prevailing social values.

\section{Tax Avoidance}

Tax avoidance is generally considered a legal action because many take advantage of loopholes in the applicable tax regulations (Lawful) (Santoso and Ning, 2013). Tax avoidance is an effort to minimize the amount of tax owed by utilizing the legislation loopholes to increase the company's profit. Efforts made 
by companies to conduct tax avoidance to increase profitability will affect the company's support to the government in realizing development and other social programs so that companies will be considered socially irresponsible (Huseynov and Klamm, 2012).

\section{Capital Intensity}

Capital Intensity Ratio is often associated with the amount of capital held by the company in fixed assets and inventory. Managers will invest the company's idle funds into the form of fixed assets to utilize depreciation as a tax deduction (Muzakki and Darsono, 2015). The greater the number of fixed assets a company, the lower the tax paid each compared to companies with low amounts of fixed assets because the number of tax expenditures that the company should pay will be reduced from the depreciation expense on fixed assets.

$H_{1}$ : Capital Intensity has a significant positive effect on Tax Avoidance

\section{Sales Growth}

Sales growth reflects manifestations of past investment success and can be used as a prediction of future growth (Masrullah et al., 2018). Increased sales growth is likely to make the company a big profit, encouraging companies to practice tax avoidance (Dewinta and Setiawan, 2016). Growing sales growth will increase the company's profits, so the corporate tax expenses are also increasing.

$\mathrm{H}_{2}$ : Sales Growth has a significant positive effect on Tax Avoidance

\section{Corporate Social Responsibility (CSR)}

The company conducts CSR disclosures to gain positive legitimacy from the community to maintain the company's survival. It is for-profit and the company to operate per the limits of the norms and values applicable in the community (Pradipta and Supriyadi, 2015). One form of social responsibility that companies can do is comply with paying taxes to the government to realize sustainable development to realize a just and prosperous society.

$\mathrm{H}_{3}$ : Corporate Social Responsibility has a significant positive effect on Tax Avoidance

\section{Company Size}

Companies with a large number of fixed assets will also lower the amount of the tax paid. This condition indicates that companies with high fixed asset rates have a lower tax expense than companies with common fixed assets (Sinaga and Sukartha, 2018). The company's size can be seen from the total number of assets owned; the more significant the company's total asset, the larger the size of the company. The company's size indicates a sizeable fixed investment, allowing the company to minimize the tax expense to be paid cause depreciation of the depreciation of its fixed assets.

$\mathrm{H}_{4}$ : Company Size strengthens Capital Intensity has a significant positive effect on Tax Avoidance 


\section{Company Size with Sales Growth}

Sales have a significant influence on the company, where the sale of the company must be supported by property or assets, where if the deal is increased, then the company's assets must also be added. The increase in sales growth is likely to make the company a big profit so that the company tends to practice tax avoidance (Lestari et al., 2018). The increasing number of sales caused by the company's size resulted in the company's increasing profits, encouraging the company's managers to practice tax avoidance to make a high profit.

$H_{5}$ : Company Size strengthens Sales Growth to have a significant positive effect on Tax Avoidance

\section{Company Size with Corporate Social Responsibility}

Companies conduct operations not only for profit but also for the norms and values applicable in the community(Pradipta and Supriyadi, 2015). Corporate social responsibility will be higher judging by the larger the size of the company. This condition encourages the company to spend more as a form of responsibility to the community and the environment without assessing how much it incurred to pay its tax burden.

$H_{6}$ : Company Size strengthens Corporate Social Responsibility has a significant positive effect on Tax Avoidance

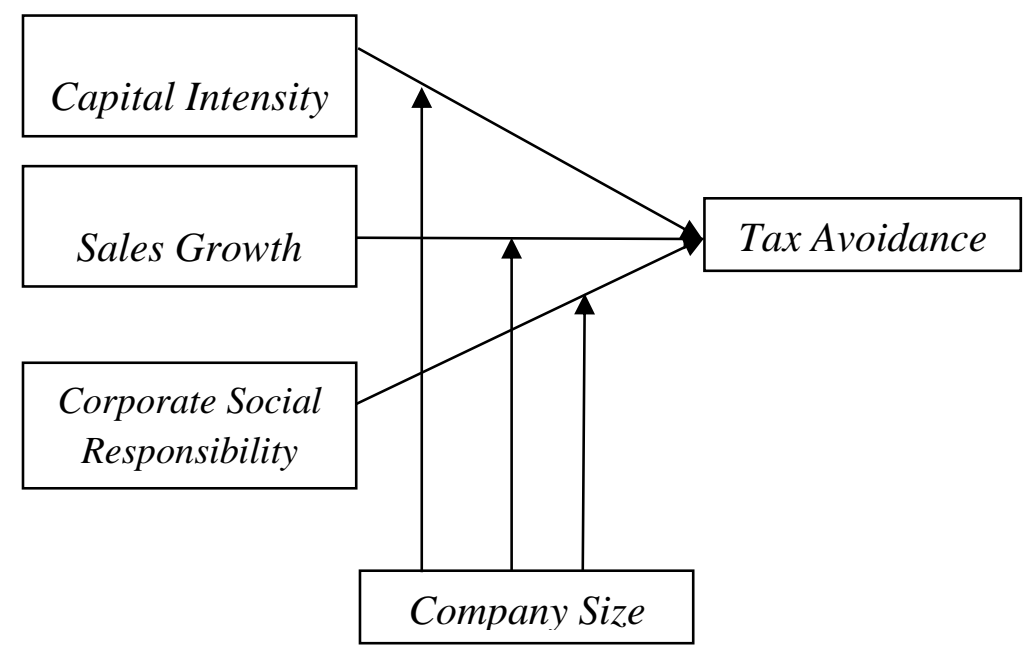

Figure 1. Conceptual Framework

\section{METHODOLOGY}

This research is a type of quantitative research, in this study using Agency Theory and Legitimacy Theory. The population in this study is all mining companies listed on the Indonesia Stock Exchange in 2014-2018. Determination of research samples based on purposive sampling method with a total of 85 samples. Research data is secondary data accessed through www.idx.co.id. Data analysis uses multiple linear regression analysis for capital intensity, sales 
growth, and CSR against tax avoidance. Analysis of logistic regression with Absolute Difference Value test for company size strengthens capital intensity, sales growth, and CSR to tax avoidance.

Data collection is done by documentation method, which is to browse the annual report selected into the sample. The yearly information is obtained from the publication of the Indonesia Stock Exchange through www.idx.co.id in the period 2014-2018. The form of instruments used in this research is a form of documentation where this form is categorized into two kinds of documentation by containing the outlines or categories that the data will look for and a checklist having a list of variables that the data will collect. The data processing technique employs the SPSS application. The following are analyses and testing: descriptive statistic, classic assumption test (normality test, multicollinearity test, autocorrelation test, heteroscedasticity test), and hypothesis test (Sugiyono, 2018:147).

\section{RESULTS}

Table 1 shows the presentation of descriptive statistics of each research variable. The production of tax avoidance variables consisting of 85 financial statements studied shows that the minimum value is 0,00 and the maximum value is 1,13 so that it is obtained a range value of 1,13 . The average mean is 0,357 . The standard value of the deviation of 0,183 indicates a lower than average value, meaning that the tax avoidance in this research was relatively low during the research period. All information is in table 1.

Table 1. Classic Assumption Test

\begin{tabular}{|c|c|c|c|c|c|c|c|}
\hline \multirow{2}{*}{ Model } & \multicolumn{2}{|c|}{$\begin{array}{l}\text { Kolmogorov- } \\
\text { Smirnov }\end{array}$} & \multicolumn{2}{|c|}{$\begin{array}{l}\text { Collinearity } \\
\text { Statistics }\end{array}$} & \multirow{2}{*}{$\begin{array}{c}\text { Durbin- } \\
\text { Watson } \\
\text { DW }\end{array}$} & \multicolumn{2}{|c|}{ Glejser } \\
\hline & $\begin{array}{c}\text { K-S } \\
\text { Z }\end{array}$ & $\begin{array}{l}\text { Asymp. } \\
\text { Sig. }\end{array}$ & Tolerance & VIF & & $\mathbf{t}$ & Sig. \\
\hline (Constant) & & & & & & 0.330 & 0,742 \\
\hline $\begin{array}{l}\text { CAPITAL } \\
\text { INTENSITY }\end{array}$ & & & 0,857 & 1,166 & & $\begin{array}{r}3,350 \\
-\end{array}$ & 0,351 \\
\hline $\begin{array}{l}\text { SALES GROWTH } \\
\text { CSR }\end{array}$ & 0,327 & 0,119 & $\begin{array}{l}0,880 \\
0,938\end{array}$ & $\begin{array}{l}1,136 \\
1,066\end{array}$ & 1,894 & $\begin{array}{r}0,134 \\
0,604\end{array}$ & $\begin{array}{l}0,894 \\
0,547\end{array}$ \\
\hline COMPANY SIZE & & & 0,883 & 1,132 & & 0,357 & 0,722 \\
\hline
\end{tabular}

Source: Adapted SPSS report

The normality test results in one sample Kolmogorov-Smirnov above concluded that the data is distributed normally. The evidence can be seen observed from the obtained values above the $5 \%$ threshold point. The multicollinearity test results presented in the table above show that overall the variable has a tolerance value of no less than 0,10 and has a VIF value of no more than 10. The condition illustrates that the regression model used for free variables has no multicollinearity issues, either on independent or moderating variables. The autocorrelation test results in table 1 can be seen that Durbin Watson's value is 1,694. Based on 5\% significance with $85(\mathrm{n})$ number of analysis 
units and 3 independent variables $(k=3)$, it gets a value of $\mathrm{dl}=1,599$ and a value of $\mathrm{du}=1,696$. The DW value obtained is 1,894 , which means it is between du and 4-du. DW value of 1,894 more than du $(1,696)$ and less than 4 -du $(2,304)$, so it can be concluded that there is no autocorrelation problem in the regression model, making it feasible use in the next analysis. Based on the table above, it can be seen that all free variables have a more significant test $t$ sig value of 0,05 , indicating no heteroscedasticity.

Table 2. Summary of Relationships

\begin{tabular}{lccccc}
\hline \multirow{2}{*}{ Model } & \multicolumn{2}{c}{ F-test } & \multicolumn{3}{c}{ t-test } \\
\cline { 2 - 6 } & F & Sig. & \multicolumn{1}{c}{ B } & \multicolumn{1}{c}{ T } & Sig. \\
\hline Capital Intensity $\left(X_{1}\right)$ & & & 0,069 & 1,985 & 0,033 \\
Sales Growth $\left(X_{2}\right)$ & 4,898 & \multirow{2}{*}{0,036} & 0,004 & 1,878 & 0,041 \\
Csr $\left(X_{3}\right)$ & & & 0,505 & 2,334 & 0,021 \\
Company Size $\left(X_{4} / \mathrm{M}\right)$ & & & 0,386 & 0,217 & 0,429 \\
$X_{1}$ M & & & $-3,418$ & $-0,857$ & 0,393 \\
$X_{2}$ M & & & 0,108 & 1,788 & 0,032 \\
$X_{3}$ M & & & 10,056 & 2,063 & 0,040 \\
\hline
\end{tabular}

Source: Adapted SPSS Output

Table 2 shows the influence of capital intensity, sales growth, and corporate social responsibility on tax avoidance has an F-count value of 4,898 with a significant level of 0,036 . The gain of such significance is smaller than $5 \%$ $(\mathrm{a}=0,05)$, and the F-count value of 4,898 is greater than the table's $\mathrm{F}$ value of 3,107891 (df1=3-1=2 and $\mathrm{df} 2=85-3=82$ ), which means that $\mathrm{H}_{1}, \mathrm{H}_{2}$, and $\mathrm{H}_{3}$ are accepted. The test results for the entire hypothesis are shown in table 3.

Table 3. Hypothesis Test Result

\begin{tabular}{|c|c|c|}
\hline Hypothesis & Statement & Result \\
\hline $\mathrm{H}_{1}$ & $\begin{array}{l}\text { Capital Intensity has a significant } \\
\text { positive effect on Tax Avoidance }\end{array}$ & Hypothesis is accept \\
\hline $\mathrm{H}_{2}$ & $\begin{array}{l}\text { Sales Growth has a significant positive } \\
\text { effect on Tax Avoidance }\end{array}$ & Hypothesis is accept \\
\hline $\mathrm{H}_{3}$ & $\begin{array}{l}\text { Corporate Social Responsibility has a } \\
\text { significant positive effect on Tax } \\
\text { Avoidance }\end{array}$ & Hypothesis is accept \\
\hline $\mathrm{H}_{4}$ & $\begin{array}{l}\text { Company Size strengthens Capital } \\
\text { Intensity has a significant positive effect } \\
\text { on Tax Avoidance }\end{array}$ & Hypothesis is rejected \\
\hline $\mathrm{H}_{5}$ & $\begin{array}{l}\text { Company Size strengthens Sales } \\
\text { Growth to have a significant positive } \\
\text { effect on Tax Avoidance }\end{array}$ & Hypothesis is accept \\
\hline $\mathrm{H}_{6}$ & $\begin{array}{l}\text { Company Size strengthens Corporate } \\
\text { Social Responsibility has a significant } \\
\text { positive effect on Tax Avoidance }\end{array}$ & Hypothesis is accept \\
\hline
\end{tabular}




\section{DISCUSSION}

The first hypothesis presented in this research is that capital intensity has a positive effect on tax avoidance. The results of the analysis showed that capital intensity has a significant positive impact on tax avoidance. That is means the first hypothesis is accepted. This research shows that the company utilizes depreciation of its fixed assets to reduce the amount of tax to be paid. Management will invest fixed assets using the company's idle funds to benefit from depreciation costs used as tax deductions.

The second hypothesis presented in this research is that sales growth has a positive effect on tax avoidance. The results showed that sales growth has a significant positive impact on tax avoidance. That is means a second hypothesis is accepted. This research shows that the increasing sales growth will cause the company's profits to increase, so the corporate tax expense is also growing. Growing corporate profits will motivate the company manager to reduce his tax amount to earn a significant gain under the company's main objectives.

The third hypothesis presented in this research is that corporate social responsibility positively affects tax avoidance. The analysis results showed that corporate social responsibility has a significant positive effect on tax avoidance, or the third hypothesis is supported. Based on the test results that have been done, CSR has a positive impact on tax avoidance. The higher the CSR disclosure of a company, the higher the tax avoidance is carried out.

The results of the moderation regression analysis using the absolute difference value approach show that the interaction of company size and capital intensity to tax avoidance is a moderating variable with significant results. The research showed that company size does not strengthen capital intensity on tax avoidance, meaning that the fourth hypothesis stating that the company size reinforces capital intensity on tax avoidance is not supported or rejected. The company size cannot interact with the relationship of capital intensity to tax avoidance. The larger a company, the greater its operational activities, and to support the operational activities, the company will need an enormous fixed asset. The number of such assets will incur a high depreciation expense.

The results of the moderation regression analysis using the absolute difference value approach show that the interaction of company size and sales growth against tax avoidance is a moderating variable with significant results. The result of the analysis showed that company size strengthens sales growth on tax avoidance. The fifth hypothesis is stating that the company size enhances the influence of sales growth on tax avoidance is supported or accepted. This research shows that the increasing sales growth will cause the company's profits to increase as well so that the corporate tax expense also increases and motivates managers to do tax avoidance. The increasing number of sales caused by the company's size resulted in its growing profits making it difficult for the company to minimize its tax expense.

The results of the moderation regression analysis using the absolute difference value approach show that the interaction of company size and corporate social responsibility to tax avoidance is a moderating variable with significant results. The analysis showed that company size strengthens 
corporate social responsibility on tax avoidance, supporting the sixth hypothesis that company size enhances the influence of corporate social responsibility on tax avoidance is supported or accepted. This research shows that large corporations will do tax avoidance by spending CSR costs so that the tax burden will be reduced. Corporate social responsibility will be higher judging by the more significant the company's size because the more coverage and reach to be considered relates to the environment and the surrounding community.

\section{FURTHER STUDY}

Variables in this study are only measured by capital intensity, sales growth, and corporate social responsibility that have a minimal influence, so there are most likely other factors that can also influence tax avoidance for future research. Further research should consider some other variables that may affect the value of companies to increase knowledge about tax avoidance.

\section{ACKNOWLEDGMENT}

The author would like to acknowledge that the financial support provided by the research grant of Universitas Islam Negeri Alauddin Makassar, Indonesia.

\section{REFERENCES}

Abdullah, M. W, dan Yuliana. (2018). Corporate Environmental Responsibility: An Effort To Develop A Green Accounting Model. Jurnal Akuntansi, 12(3): 305-320.

Abdullah, M. W., A. B. Salleh., H. Hanafie, dan A. Y. M. Bayan. (2020). Maqasid Al-Syariah Strengthen Tax Evasion Understanding and Tax Morale to Improve Taxpayer Awareness. Journal of Critical Reviews, 7(10): 4769-4778.

Abdullah, M. W., S. Muchlis, dan S. N Sari. (2015). Pengaruh Tekanan Stakeholders dan tanggung jawab Sosial terhadap Penerapan Akuntansi Lingkungan di Kawasan Industri Makassar. ASSETS, 5(1): 105-114.

Adiatma, A. E., Siti Ragil Handayani, dan Kadarisman Hidayat. (2015). Pengaruh Edukasi, Sosialisasi, dan Himbauan Terhadap Kepatuhan Wajib Pajak Dalam Melaporkan SPT Tahunan Pajak Penghasilan. Jurnal Perpajakan (JEJAK), 8(1): 1-8.

Apriliani, M, dan M. W. Abdullah. (2018). Falsafah Kesenian Tanjidor pada Pelaksanaan Corporate Social Responsibility. Jurnal Akuntansi Multiparadigma, 9(2): 377-393.

Dewinta, I. A. R. dan Putu Ery Setiawan. (2016). Pengaruh Ukuran Perusahaan, Umur Perusahaan, Profitabilitas, Leverage, dan Pertumbuhan Penjualan terhadap Tax Avoidance. E-Jurnal Akuntansi Univesitas Udayana. 14(3): 1584-1613. 
Dharma, N. B. S. dan Naniek Noviari. (2017). Pengaruh Corporate Social Responsibility dan Capital Intensity Terhadap Tax Avoidance. E-Jurnal Akuntansi Universitas Udayana, 18(1): 529-556.

Dowling, J. dan Preffer, J. (1975). Organisational Legitimacy : Social Values and Organisational Behavior. Pacific Sociological Review, 18: 122-36.

Fadjarenie, A. dan Yulia Apni Nur Anisah. (2016). Pengaruh Corporate Governance dan Sales Growth Terhadap Tax Avoidance (Studi Empiris pada Perusahaan Otomotif yang Terdaftar di Bursa Efek Indonesia Tahun 2010-2014). Jurnal Study \& Accounting Research (STAR), 13(3): 48-58

Hantoyo, S. S., Kertahadi, dan Siti Ragil Handayani. (2016). Pengaruh Penghindaran Pajak dan Sanksi Perpajakan Terhadap Kepatuhan Wajib Pajak. Jurnal Perpajakan (JEJAK), 9(1): 1-8.

Hoi, C. K., Qiang Wu, dan Hao Zhang. (2013). Is Corporate Social Responsibility (CSR) Associated with Tax Avoidance? Evidence from Irresponsible CSR Activities. The Accounting Review. 88(6): 2025-2059.

Jensen, M.C. dan W.M. Meckling. (1976). Theory of the firm: Managerial Behavior, Agency Cost, and Ownership Structure. Journal of Financial Economics, 3: 305-360.

Lestari, P., Fadjar Harimurti, dan Suharno. (2018). Pengaruh Karakteristik Perushaan dan sales Growth Terhadap Tax Avoidance (Studi Kasus pada Perushaan Manufaktur Sektor Makanan dan Minuman yang Terdaftar di BEI tahun 2013-2016). Jurnal Akuntansi dan Sistem Teknologi Informasi. 14(4): 551-559.

Masrullah, Mursalim, dan M. Su'un. (2018). Pengaruh Kepemilikan Institusional, Komisaris Independen, Leverage dan Sales Growth Terhadap Tax Avoidance pada Perusahaan Manufaktur di Bursa Efek Indonesia. SiMAK, 16(2): 142-165.

Muzakki, M. R. dan Darsono. (2015). Pengaruh Corporate Social Responsibility dan Capital Intensity terhadap Penghindaran Pajak. Diponegoro Journal of Accounting, 4(3): 1-8.

Pradipta, D.H., and Supriyadi. (2015). Pengaruh Corporate Social Responsibility (CSR), Profitabilitas, Leverage dan Komisaris Independen Terhadap Praktik Penghindaran Pajak. Simposium Nasional Akuntansi 18.

Putra, I G. L. N. C. dan N. K. L. A. Merkusiwati. (2016). Pengaruh Komisaris Independen, Leverage, Size, dan Capital Intensity Ratio pada Tax Avoidance. E-Jurnal Akuntansi Universitas Udayana, 17(1): 690-714.

Sinaga, R. R. dan I M. Sukartha. 2018. Pengaruh Profitabilitas, Capital Intensity Ratio, Size, dan Leverage pada Manajemen Pajak Perusahaan Manufaktur di Bursa Efek Indonesia Periode 2012-2015. E-Jurnal Akuntansi Universitas Udayana, 22(3): 2177-2203.

Wardani, D. K. dan D. Khoiriyah. (2018). Pengaruh Strategi Bisnis dan Karakteristik Perusahaan terhadap Penghindaran Pajak. Akuntansi Dewantara, 2(1): 25-36. 